\title{
Protection from liver-stage malaria is dependent on a fine balance between the number of infected hepatocytes and effector $\mathrm{CD} 8^{+} \mathrm{T}$ cells
}

\author{
Alexandra Spencer*, Rhea Longley, Anita Gola, Teresa Lambe, Adrian Hill \\ From Challanges in malaria research: Core science and innovation \\ Oxford, UK. 22-24 September 2014
}

\section{Background}

Since the demonstration of sterile protection afforded by injection of irradiated sporozoites, $\mathrm{CD}^{+} \mathrm{T}$ cells have been shown to play a significant role in protection from liver-stage malaria. This is, however, dependent on the presence of an extremely high number of circulating effector cells, thought to be necessary to scan, locate and kill infected hepatocytes in the short time that parasites are present in the liver. To this day very little is known about the $\mathrm{T}$ cell response to malaria in the liver, therefore we have utilized an adoptive transfer system in mice to elucidate the kinetics of $\mathrm{CD}^{+} \mathrm{T}$ cell mediated protection following sporozoite challenge.

\section{Materials and methods}

Balb/c mice were immunized with viral vectors expressing the immunodominant epitope from $P$. berghei CS protein, $\mathrm{Pb} 9$, to induce high numbers of antigen specific $\mathrm{CD}^{+} \mathrm{T}$ cells that were transferred into recipient mice. By CFSE labeling cells we were able to track $\mathrm{CD} 8^{+} \mathrm{T}$ cell migration into the liver and recruitment of cells into division by flow cytometry in the days following sporozoite challenge.

\section{Results and conclusions}

To our surprise we did not detect active recruitment of $\mathrm{CD}^{+} \mathrm{T}$ cells into the liver or liver draining lymph nodes in the early days following sporozoite challenge. Cell division was also not required for protection as divided cells were only detected 3 days after challenge. In addition CD8 ${ }^{+} \mathrm{T}$ cells were shown to only require 24 hours to locate and kill infected hepatocytes. By titrating the number of transferred cells and sporozoites we discovered a threshold

University of Oxford, Oxford, UK any medium, provided the original work is properly cited. The Creative Commons Public Domain Dedication waiver (http:// creativecommons.org/publicdomain/zero/1.0//) applies to the data made available in this article, unless otherwise stated. 